\title{
Effects of Isoprenaline Plus Phenylephrine by Pressurized Aerosol on Blood Gases, Ventilation, and Perfusion in Chronic Obstructive Lung Disease
}

\author{
L. H. HARRIS, ${ }^{*}$ M.B., B.S., M.R.C.P.ED.
}

\begin{abstract}
Cummary: The effects of a combined isoprenaline$\checkmark$ phenylephrine inhalant in chronic obstructive lung disease were assessed in 23 patients. Significant changes occurred in blood gas tensions after inhalation, together with an overall improvement in ventilation/perfusion ratios. Cardiac output and physiological shunt were not significantly increased. Hence the addition of phenylephrine probably prevents the increase of hypoxaemia which may result from the disproportionate ventilation/ perfusion ratio produced by sympathomimetics or xanthines used alone. The combination aerosol has a satisfactory bronchodilator effect, and is additionally safe if used by a severely hypoxic patient unaware of the seriousness of his condition.
\end{abstract}

\section{Introduction}

A fall in arterial oxygen tension or saturation may be produced by intravenous aminophylline (Halmagyi and Cotes, 1959; Daly and Howard, 1965; Rees et al., 1967a, 1968; Tai and Read, 1967a), subcutaneous adrenaline (Halmagyi and Cotes, 1959; Rees et al., 1967b, 1968), isoprenaline inhalation (Chapman and Hughes, 1966; Field, 1967; Lockhart et al., 1967; Knudson and Constantine, 1967; Palmer and Diament, 1967, 1968; Tai and Read, 1967a; Waddell et al., 1967; McDonald et al., 1968; Chapman, 1969; Chapman and Dowd, 1969; Warrell et al., 1970), orciprenaline inhalation (Stiksa et al., 1967; Chapman, 1969), salbutamol inhalation (Bass et al., 1969; Chapman, 1969; Hume, 1970), papaverine and papaverine plus isoprenaline inhalation (Chapman and Dowd, 1969), and atropine subcutaneously (Field, 1967). On theoretical grounds this fall could be prevented by adding a pulmonary vasoconstrictor or a cardiac slowing drug to a beta-adrenergic bronchodilator. The present study was undertaken to explore this possibility by using an aerosol consisting of isoprenaline and phenylephrine. $\dagger$ A blind comparative trial with isoprenaline was not considered necessary since the effects of isoprenaline alone are fully recorded.

\section{Patients}

All 23 patients selected had chronic obstructive lung disease with known reversibility of expiratory airflow obstruction as shown by increase in $\mathrm{FEV}_{1}$ greater than $20 \%$ following 0.5 mg. of adrenaline subcutaneously on at least one previous occasion. The patients had used no bronchodilator therapy for at least the previous 12 hours. There were 17 men aged $37-67$ (mean. 55) and six women aged 38-66 (mean 52).

\section{Methods}

Measurements were made initially after inhalation of inert propellent and then 30 minutes after inhalation of two * Consultant Chest Physician, Newsham General Hospital, Liverpool 6,
and Fazakerley Hospital, Liverpool 9. + Medihaler-duo-isoprenaline hydrochloride $0.16 \mathrm{mg}$. and phenylephrine
bitartrate $0.24 \mathrm{mg}$. per "puff." "puffs" of Medihaler-duo. The aerosol was on every occasion used under the direct supervision of the investigator. If a patient was not familiar with the device it was manipulated by the investigator personally.

$\mathrm{FEV}_{1}$ was taken as the best of three attempts on a Vitalograph Spirometer. Values were corrected to body temperature, pressure, and saturation (B.T.P.S.). Minute ventilation was measured as inspiratory volume $\left(\dot{V}_{1}\right)$ over a fiveminute period with a Parkinson-Cowan dry gas meter, and respiratory frequency was recorded simultaneously. $\dot{V}_{I}$ was converted to expiratory volume $\left(\dot{\mathrm{V}}_{\mathrm{E}}\right)$ by the formula $\dot{\mathrm{V}}_{\mathrm{E}}=\dot{\mathrm{V}}_{1}$ $\times \mathrm{F}_{\mathrm{I}} \mathrm{N}_{2} / \mathrm{F}_{\mathrm{E}_{2}}$ and corrected to body temperature, pressure, and saturation. The patients were given time to get used to nose-clip and mouthpiece, and measurements were recorded only after $\dot{V}_{I}$ has become stabilized over a period of at least three minutes.

Expired air was collected for five minutes in a 100-litre Douglas bag by means of a low-resistance one-way valve and analysed for $\mathrm{CO}_{2}$ and $\mathrm{O}_{2}$. Nitrogen was calculated as $100-\mathrm{F}_{\mathrm{E}} \mathrm{O}_{2}-\mathrm{F}_{\mathrm{E}} \mathrm{CO}_{2}$. Oxygen was measured with a Servomex paramagnetic $\mathrm{O}_{2}$ analyser calibrated with oxygen-free nitrogen and room air. Carbon dioxide was measured with a HilgerIRD infrared $\mathrm{CO}_{2}$ analyser calibrated with gases of known $\mathrm{CO}_{2}$ and $\mathrm{O}_{2}$ content. Calibration gases were analysed for $\mathrm{CO}_{2}$ with a modified Haldane apparatus. Oxygen consumption $\left(\dot{\mathrm{V}}_{2}\right)$ and carbon dioxide output $\left(\dot{\mathrm{V}} \mathrm{CO}_{2}\right)$ were then calculated with correction to standard temperature and pressure, dry (S.T.P.D.). Oxygenated mixed venous $\mathrm{PCO}_{2}$ was measured by a "trial and error" rebreathing equilibration method using $\mathrm{CO}_{2} / \mathrm{O}_{2}$ mixtures of known composition, until an acceptable plateau was obtained on the rapid $\mathrm{CO}_{2}$ analyser tracing (Hackney et al., 1958).

Blood gases and hydrogen ion concentration were measured on an IL blood gas analyser incorporating a Severinghaus type $\mathrm{PCO}_{2}$ microelectrode and a Clarke type $\mathrm{Po}_{2}$ microelectrode. Samples were taken from the hyperaemic ear-lobe into heparinized capillary tubes and analysed promptly. The earlobe was rendered hyperaemic by vigorous massage for three minutes with a cream containing thurfyl nicotinate. Langlands and Wallace (1965) reported a close correlation between the results obtained from gas-analysis of blood from the hyperaemic ear-lobe and that taken from the brachial artery, and MacIntyre et al. (1968) confirmed their findings with the technique used in the present study.

"Physiological" dead-space/tidal volume ratio was calculated from the formula $\mathrm{V}_{\mathrm{D}} / \mathrm{V}_{\mathrm{E}}=\mathrm{PaCO}_{2}-\mathrm{P}_{\mathrm{E}} \mathrm{CO}_{2} / \mathrm{PaCO}_{2}$; with correction for valve box dead space of $35 \mathrm{ml}$. Alveolar ventilation was calculated from the formula $\dot{\mathrm{V}}_{A}=\dot{\mathrm{V}}_{\mathrm{E}}\left(1-\mathrm{V}_{\mathrm{D}} / \mathrm{V}_{\mathrm{E}}\right)$. Oxygen saturation was obtained from the Severinghaus nomogram with corrections for $\mathrm{pH}$ and temperature. Blood $\mathrm{CO}_{2}$ content was derived from the tables of $\mathrm{McHardy}$ (1967).

Ventilation-perfusion ratio was calculated from the formula $\dot{\mathrm{V}}_{\mathrm{A}} / \dot{\mathrm{Q}}_{\mathrm{T}}=0.863 \times\left(\mathrm{C} \overline{\mathrm{v}} \mathrm{CO}_{2}-\mathrm{CaCO}_{2}\right) / \mathrm{PaCO}_{2}$. $\dot{\mathrm{Q}}_{\mathrm{T}}$ was derived from this by substituting the value previously calculated for $\dot{\mathrm{V}}_{\mathrm{A}}$.

Arterial $\left(\mathrm{CaO}_{2}\right)$ and pulmonary capillary $\left(\mathrm{CcO}_{2}\right)$ contents were obtained from the tables of Kelman and Nunn (1966), pulmonary capillary $\mathrm{Po}_{2}$ being assumed to be $2 \mathrm{~mm}$. lower than calculated alveolar $\mathrm{Po}_{2}$. Alveolar $\mathrm{Po}_{2}$ was calculated from the formula: $\mathbf{P A O}_{2}=\left(\mathbf{P}_{1} \mathrm{O}_{2}-\mathrm{PaCO}_{2} / \mathbf{R}\right)+\left(\mathbf{P a C O}_{2} / \mathbf{R} \times \mathbf{F}_{\mathbf{1}} \mathrm{O}_{2}(\mathbf{1}-\mathbf{R})\right.$. 
Mixed venous oxygen content $\left(\mathrm{C}_{\mathrm{v}} \mathrm{O}_{2}\right)$ was calculated by rearrangement of the relationship $\dot{\mathrm{Q}}_{\mathrm{T}}=\dot{\mathrm{V}}_{2} / \mathrm{CaO}_{2}-\mathrm{C} \overline{\mathrm{v}} \mathrm{O}_{2}$. "Physiological-shunt" was calculated from the formula $\dot{\mathrm{Q}}_{\mathrm{S}} / \dot{\mathrm{Q}}_{\mathrm{T}}=\left(\mathrm{C}_{2}-\mathrm{CaO}_{2}\right) /\left(\mathrm{CcO}_{2}-\mathrm{CrO}_{2}\right) \times 100$.

\section{Results}

Though previously demonstrated reversibility of expiratory airflow obstruction was the criterion for entry into the trial, on their test days only 13 of the 23 patients showed an increase in $\mathrm{FEV}_{1}$ of $20 \%$ or more. This day-to-day variability in response to bronchodilator drugs is well known to all experienced investigators and has been documented by Hume and Gandevia (1957) and Altounyan (1964). The results have therefore been separated into two groups: "responders" showing $\mathrm{FEV}_{1}$ increase greater than $20 \%$ and "non-responders" showing $\mathrm{FEV}_{1}$ increase less than $20 \%$. All the variables have been statistically analysed by testing for the significance of mean differences by a $t$ test (Mainland, 1963).

\section{Ventilation}

Responders.-Figs. 1-4 show $\mathrm{FEV}_{1}, \dot{\mathrm{V}} \mathrm{CO}_{2}, \mathrm{~V}_{\mathrm{D}} / \mathrm{V}_{\mathrm{E}}$, and $\dot{\mathrm{V}}_{\mathrm{A}}$ before and after inhalation. There were significant increases in $\mathrm{FEV}_{1}(\mathbf{P}<0.001), \dot{\mathrm{V}}_{2}(\mathbf{P}<0.05)$, and $\dot{\mathrm{V}}_{\mathbf{A}}(\mathrm{P}<0.05)$ with a significant decrease in $V_{D} / V_{E}(P<0.01)$ indicating an increase in effective ventilation. $\dot{\mathrm{V}}_{\mathrm{E}}$ and $\dot{\mathrm{V}}_{2}$ changes did not reach statistical significance.

Non-responders.-There were no significant changes in any of these variables.

\section{Blood gases}

Responders.-Figs. 5 and 6 show $\mathrm{PaO}_{2}$ and $\mathrm{PaCO}_{2}$ before and after inhalation. The increase in $\mathrm{PaO}_{2}$ is significant $(\mathrm{P}<0.02)$ and the decrease in $\mathrm{PaCO}_{2}$ is significant $(\mathbf{P}<0.02)$. This, too, indicates the efficacy of the increased ventilation. There were no significant changes in arterial oxygen saturation, which is not surprising as most patients had only minimal hypoxaemia. No significant changes were found in $\mathrm{pH}$.

Non-responders.-There were no significant changes in any of the variables.

\section{Cardiac Output and Physiological Shunt}

Responders.-Figs. 7 and 8 show $\dot{\mathrm{Q}}_{\mathrm{T}}$ and $\dot{\mathrm{Q}}_{\mathrm{S}} / \dot{\mathrm{Q}}_{\mathrm{T}} \%$, before and after inhalation. There was no significant change in either variable, which suggests that any cardiovascular response was minimal.

Non-responders.-There was no significant change in either variable, supporting the suggestion that any cardiovascular response was minimal.
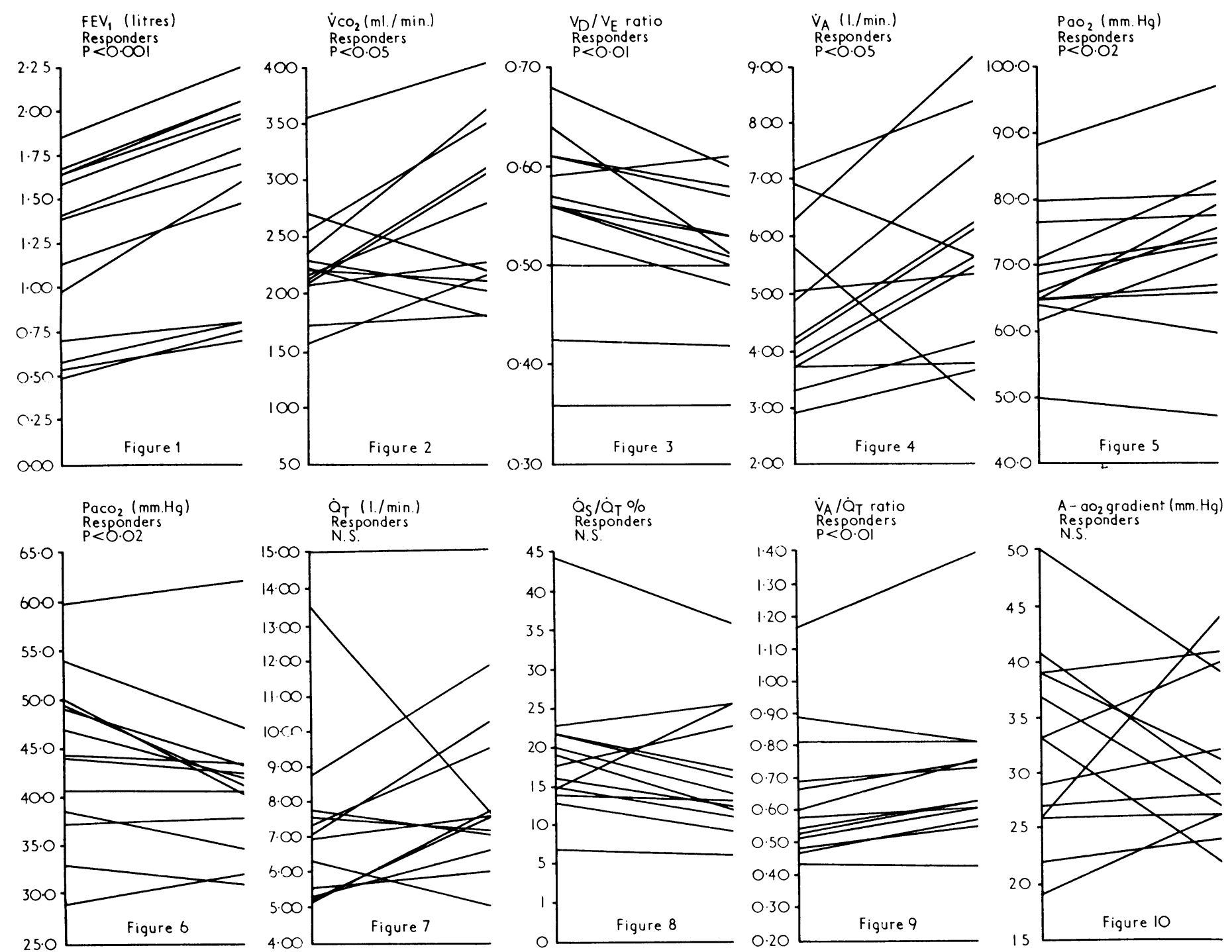

Figs. 1-10 Changes in $\mathrm{FEV}_{1}, \dot{\mathrm{V}}_{2}, \mathrm{~V}_{\mathrm{D}} / \mathrm{V}_{\mathrm{E}}, \dot{\mathrm{V}}_{\mathrm{A}}, \mathrm{PaO}_{2}, \mathrm{PaCO}_{2}, \dot{\mathrm{Q}}_{\mathrm{T}}, \dot{\mathrm{Q}}_{\mathrm{S}} / \dot{\mathrm{Q}}_{\mathrm{T}}, \dot{\mathrm{V}}_{\mathrm{A}} / \dot{\mathrm{Q}}_{\mathrm{T}}$. A-ao $\mathrm{A}_{2}$ before and 30 minutes 13 cases showing a $20 \%$ or more increase in FEV 


\section{Ventilation-perfusion}

Responders.-Figs. 9 and 10 show $\dot{\mathrm{V}}_{\mathrm{A}} / \dot{\mathrm{Q}}_{\mathrm{T}}$ and $\mathrm{P}(\mathrm{A}-\mathrm{a}) \mathrm{O}_{2}$ before and after inhalation. There was a significant increase $(\mathbf{P}<0.01)$ in $\dot{\mathrm{V}}_{\mathrm{A}} / \dot{\mathrm{Q}}_{\mathrm{T}}$, indicating an improvement in overall ventilation-perfusion ratios. There was no significant change in alveolar-arterial oxygen gradient. This may be explained by the fact that the increased ventilation increased alveolar $\mathrm{Po}_{2}$ by the same amount as the arterial $\mathrm{PO}_{2}$ increase. Had there been any significant degree of pulmonary vasodilatation, increased shunting, or increased cardiac output the rise in $\mathrm{PAO}_{2}$ would not have been reflected in the $\mathrm{PaO}_{2}$, and the gradient would have widened because areas of localized underventilation are equivalent, in terms of gaseous exchange, to areas of localized overperfusion.

Non-responders.-Neither variable showed significant change.

\section{Discussion}

The mechanism by which isoprenaline and similar drugs produce a fall in arterial oxygen tension has not been fully established. Possibly in some cases of chronic obstructive lung disease there is a reduction of perfusion to underventilated alveoli, which tends to restore ventilation-perfusion ratios towards normal. On this basis it is then possible to explain the increased hypoxaemia produced by beta-adrenergic-stimulating drugs as the result of disproportionately increased perfusion. If the increased perfusion is relatively greater than the increased ventilation produced, then there will be an adverse effect on ventilation-perfusion ratios.

The increased perfusion may be due to localized pulmonary vasodilatation (beta 2 -adrenergic effect on vessels) or to increased cardiac output (beta 1 -adrenergic effect on myocardium). Palmer et al. (1969) suggested that the latter mechanism is responsible because of the action of practolol (a selec-

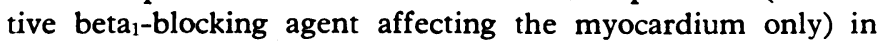
preventing isoprenaline-induced increase in hypoxaemia. The falls in $\mathrm{PaO}_{2}$ after inhalation of salbutamol, reported by Bass et al. (1969), Chapman (1969), and Hume (1970), however, are difficult to explain on this basis, since salbutamol, as a result of its selective action on beta ${ }_{2}$-adrenergic receptors, is claimed to have a minimal effect on the myocardium (Brittain et al., 1968; Kennedy and Simpson, 1969; Palmer et al., 1969).

The present study shows that the combination of isoprenaline plus phenylephrine does not cause the increase in hypoxaemia which may occur when sympathomimetics or xanthines are used alone. Indeed, the reverse occurs, with increase in $\mathrm{PaO}_{2}$ and decrease in $\mathrm{PaCO}_{2}$. This effect is explicable in terms of increased effectiveness of the improved ventilation as shown by the increases in $\mathrm{CO}_{2}$ output and alveolar ventilation in the responding group and highly significant decreases in physiological dead-space/tidal-volume ratio.

Though the indirect $\mathrm{CO}_{2}$ Fick method of calculating cardiac output may be unreliable in the resting state, the high metabolic rate of the subjects would appear to have justified its use, in accordance with the views of Warrell et al. (1970). The absence of change in cardiac output and in physiological shunt in this study suggests that phenylephrine prevented the increase which would have been expected from the use of isoprenaline alone whether or not any bronchial response occurred. This accords with previous reports that phenylephrine alone reduces cardiac output and that it is a pulmonary vasoconstrictor (Horvath and Knapp, 1954; Aviado and Schmidt, 1957). Hence probably both mechanisms may be involved in the prevention of deterioration in ventilationperfusion relationships which may be produced by isoprenaline.

The degree of fall in $\mathrm{PaO}_{2}$ produced by bronchodilators is generally small but in some patients may be as much as 15 $\mathrm{mm}$. Hg. The Table gives the numbers of patients showing a fall in $\mathrm{PO}_{2}$ of more than $5 \mathrm{~mm}$. $\mathrm{Hg}$ extracted from those papers in which individual results were recorded. As an approximate estimate (since papers reporting only group
Number of Patients with fall in $\mathrm{PaO}_{2}$ greater than $5 \mathrm{~mm}$. $\mathrm{Hg}$, compiled from World Literature where Individual Figures were Recorded

\begin{tabular}{|c|c|c|c|c|c|}
\hline \multicolumn{4}{|l|}{ Authors } & $\begin{array}{l}\text { No. of Patients } \\
\text { Studied }\end{array}$ & \multirow[t]{2}{*}{$\begin{array}{l}\text { No. with Fall } \\
\text { in } \mathrm{PaO}_{2} \text { of } \\
5 \mathrm{~mm} \text {. } \mathrm{Hg}\end{array}$} \\
\hline \multirow{7}{*}{\multicolumn{2}{|c|}{$\begin{array}{l}\text { Chapman and Hughes (1966) } \\
\text { Knudson and Constantine (1967) } \\
\text { Waddell et al. (1967) } \\
\text { Tai and Read (1967a) } \\
\text { Chapman and Dowd (1969)* } \\
\text { Warrell et al. (1970) }\end{array}$}} & \multicolumn{2}{|c|}{ Isoprenaline } & \multirow{5}{*}{$\begin{array}{r}8 \\
10 \\
9 \\
16 \\
12 \\
4\end{array}$} & \\
\hline & & . & $\cdots$ & & \multirow{4}{*}{$\begin{array}{l}7 \\
5 \\
2 \\
5 \\
7 \\
1\end{array}$} \\
\hline & & & $\because$ & & \\
\hline & & $\ldots$ & $\ldots$ & & \\
\hline & & . & $\cdots$ & & \\
\hline & & & & & ( \\
\hline & & & & 59 & $27(44 \cdot 3 \%)$ \\
\hline
\end{tabular}
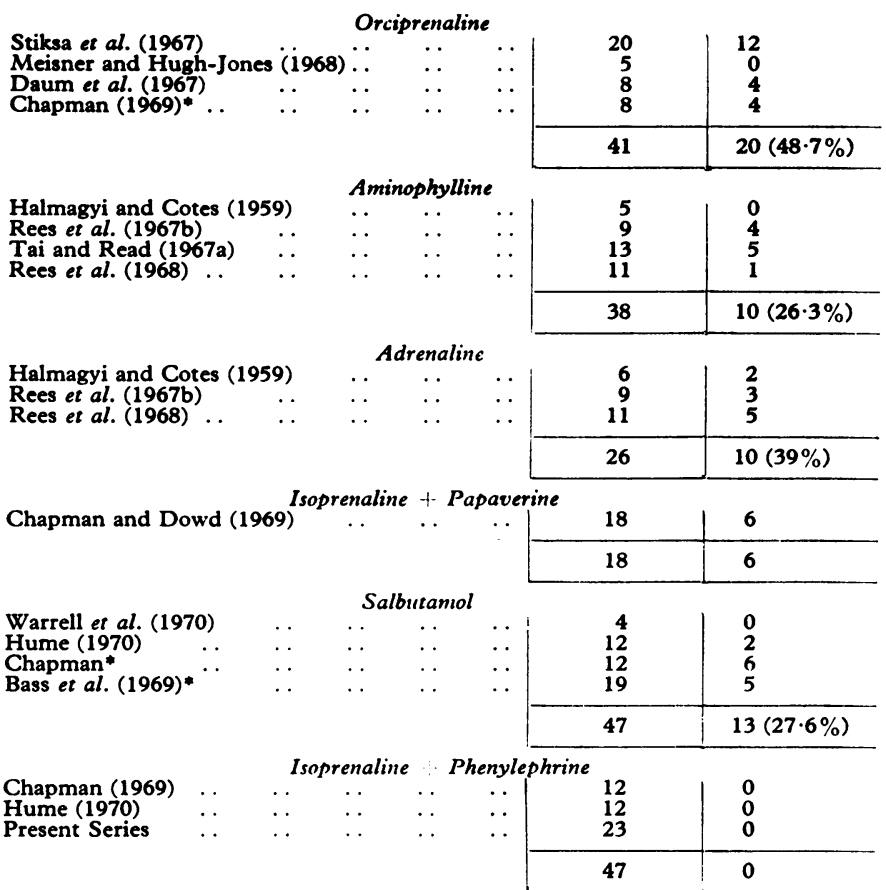

*Private communication

means had to be excluded) probably about one in three patients may be expected to show a fall. The prevention of this increase in hypoxia by using phenylephrine with isoprenaline would appear to be desirable.

Several authors have suggested that hypoxaemia may have contributed to the increase in so-called "sudden and unexpected" deaths in asthma (Chapman and Hughes, 1967; Palmer and Diament, 1967; Tai and Read, 1967a, 1967b; Read, 1968; Chapman and Dowd, 1969; Hughes, 1969). The Lancet (1968) drew attention to the fact that many patients with asthma are in a dangerous physiological state for long periods. If a patient is on the steep portion of his oxyhaemoglobin dissociation curve a fall in $\mathrm{PaO}_{2}$ of $5 \mathrm{~mm}$. $\mathrm{Hg}$, perhaps following bronchodilator treatment, could be important. A fall of $15 \mathrm{~mm}$. $\mathrm{Hg}$ might be catastrophic by causing rapid, severe desaturation.

The present results suggest that the changes in blood gases represent an improvement in the physiological state of the patients studied. The combination aerosol has a satisfactory bronchodilator effect, and may have an additional margin of safety if used by a severely hypoxic patient unaware of the seriousness of his condition.

I am grateful to Mr. J. S. Bass, of Riker Laboratories, for supplies of Medihaler-duo and to $\mathrm{Mr}$. K. Lawton, principal biochemist, Fazakerley Hospital, for blood gas measurements. Tabulated data of all the variables are available from the author on request.

REFERENCES

Altounyan, R. E. C. (1964). Thorax, 19, 406.

Aviado, D. M., and Schmidt, C. F. (1957). Fournal of Pharmacology and Experimental Therapeutics, $120,512$.

Bass, B. H., Disney, M. E., and Morrison-Smith, J. (1969). Lancet, 2, 438. 
Brittain, R. T., Farmer, J. D., Jack, D., Martin, L. E., and Simpson, W. T.

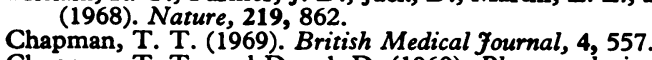

Chapman, T. T., and Dowd, D. (1969). Pharmacologia Clinica, 1, 107.

Chapman, T. T., and Hughes, D. T. (1966). Fournal of the Irish Medical Association, 59, 184.

Chapman, T. T., and Hughes, D. T. (1967). British Medical fournal, 2, 639.

Daly, J. J., and Howard, P. (1965). Thorax, 20, 324.

Daum, S., Stiksa, J., Nikodýmová, L., Petrle, A., and Svorcik, C. (1967). Arzneimittel-Forschung, 17, 565 .

Field, G. B. (1967). Clinical Science, 32, 279.
Hackney, J. D., Sears, C. H., and Collier, C. R. (1958). fournal of Applied Physiology, 12, 425 .

Halmagyi, D. F., and Cotes, J. E. (1959). Clinical Science, 18, 475.

Horvath, S. M., and Knapp, D. M. (1954). American fournal of Physiology, 178, 387.

Hume, K. M. (1970). British Medical fournal, 1, 173.

Hume, K. M., and Gandevia, B. (1957). Thorax, 12, 276.

Hughes, D. T. D. (1969). British Medical fournal, 4, 356.

Kelman, G. R., and Nunn, J. F. (1966). Computer Produced Physiological Tables. London, Butterworths.

Kennedy, M. C. S., and Simpson, W. T. (1969). British fournal of Diseases of the Chest, 63,165 .

Knudson, R. J., and Constantine, H. P. (1967). Fournal of Applied Physiology, 22, 402 .

Lancet, 1968, 1, 1412.

Langlands, J. H. M., and Wallace, W. F. M. (1965). Lancet, 2, 315.
Lockhart, A., Lissac, J., Salmon, D., Zappacosta, C., and Benismail, M. (1967). Clinical Science, 32, 17.

McDonald, I. G., Hirsch, J., Hale, G. S., Cade, J. F., and McCarthy, R. A. (1968). Medical fournal of Australia, 2, 201.

McHardy, G. J. R. (1967). Clinical Science, 32, 299.

MacIntyre, J., Norman, J. N., and Smith, G. (1968). British Medical fournal, 3,640 .

Mainland, D. (1963). Elementary Medical Statistics, 2nd edn., Philadelphia, Saunders.

Meisner, P., and Hugh-Jones, P. (1968). British Medical fournal, 1, 470

Palmer, K. N. V., and Diament, M. L. (1967). Lancet, 2, 383.

Palmer, K. N. V., and Diament, M. L. (1968). Lancet, 1, 1372.

Palmer, K. N. V., Legge, J. S., Hamilton, W. F. D., and Diament, M. L. (1969). Lancet, 2, 1092 .

Read, J. (1968). Medical fournal of Australia, 1, 879.

Rees, H. A., Borthwick, R. C. Millar, J. S., and Donald, K. W. (1967a). Lancet, $2,1167$.

Rees, H. A., Millar, J. S., and Donald, K. W. (1967b). Lancet, 2, 1164.

Rees, H. A., Millar, J. S., and Donald, K. W. (1968). Quarterly fournal of Medicine, 37, 541 .

Stiksa, J., Daum, S., and Nikodýmová, L. (1967). Arzneimittel-Forschung, $17,568$.

Tai, E., and Read, J. (1967a). Thorax, 22, 543.

Tai, E., and Read, J. (1967b). Lancet, 1, 644.

Waddell, J. A., Emerson, P. A., and Gunstone, R. F. (1967). British Medical fournal, 2, 402.

Warrell, D. A., et al. (1970). British Medical fournal, 1, 65.

\title{
Idiopathic Hypercalciuria and Hyperparathyroidism
}

\author{
PETER ADAMS, ${ }^{*}$ M.R.C.P. ; T. M. CHALMERS, ${ }^{*}$ F.R.C.P. ; L. F. HILL, $\dagger$ M.R.C.P. ; B. MCN. TRUSCOTT, $\ddagger$ F.R.C.S.
}

\begin{abstract}
Cummary: With provocative tests of parathyroid activity based on phosphate deprivation and the administration of chlorothiazide 8 out of 19 patients with idiopathic hypercalciuria developed hypercalcaemia. Five of the eight underwent exploration of the neck and four of them had parathyroid adenomas; the fifth patient had "normal" glands but responded satisfactorily to subtotal parathyroidectomy. One patient who failed to develop hypercalcaemia had primary chief cell hyperplasia of the parathyroids.
\end{abstract}

\section{Introduction}

Many patients with calcium-containing renal stones pass excessive quantities of calcium in their urine (Flocks, 1939; Hodgkinson and Pyrah, 1958). A few of these patients have hypercalcaemia and are then usually shown to have primary hyperparathyroidism. The remainder show few biochemical abnormalities other than hypercalciuria. Albright et al. (1953) and Henneman et al. (1958) recognized a group of such patients, usually men, in whom the hypercalciuria was associated with a tendency to hypophosphataemia; the serum calcium was normal, though in the upper part of the normal range. They called this syndrome idiopathic hypercalciuria and showed that urinary calcium could be reduced with calcium deprivation. Peacock et al. (1968) confirmed these observations and suggested that the intestinal absorption of calcium is increased in most patients.

The mechanisms which underlie the increased intestinal absorption of calcium in idiopathic hypercalciuria are unexplained. Peacock et al. (1968) suggested that in many cases this is the primary abnormality while others contend that the increased intestinal absorption of calcium is a secondary response to the increased losses of calcium in the urine

\footnotetext{
* Consultant Physician.

† Formerly Registrar in Medicine.

F Consultant Surgeon.

Addenbrooke's Hospital, Cambridge CB2 2QQ

Requests for reprints should be sent to Dr. T. M. Chalmers.
}

(Jackson and Dancaster, 1959; Edwards and Hodgkinson, 1965). The evidence that increased calcium absorption is the primary phenomenon is stronger. Patients with idiopathic hypercalciuria absorb more of an oral calcium load than normal (Peacock et al., 1968), and calcium deprivation does cause a major reduction in urinary calcium in many patients (Henneman et al., 1958; Harrison, 1959; Peacock et al., 1968). The apparent failure of some patients to respond in this way may be related to the severity of the calcium deprivation imposed on them (Peacock et al., 1968).

Patients with idiopathic hypercalciuria may show some of the biochemical abnormalities found in those with primary hyperparathyroidism presenting with renal stone. The urinary calcium is commonly increased in primary hyperparathyroidism, and in both conditions there is a tendency to hypophosphataemia and a reduced renal tubular reabsorption of phosphate (McGeown, 1957). In these respects the two conditions may be indistinguishable. In primary hyperparathyroidism the serum calcium is commonly increased, but even this is not a consistent or universal finding. There are several reports of patients with primary hyperparathyroidism in whom the serum calcium concentration was normal at all times (Yendt and Gagne, 1968; Wills et al., 1969).

That patients with idiopathic hypercalciuria may share abnormalities of calcium and phosphorus metabolism in common with those with primary hyperparathyroidism could suggest that the pathological basis for such abnormalities is the same in both conditions. Albright et al. (1953) attributed the changes found in phosphorus metabolism in idiopathic hypercalciuria to parathyroid overactivity. They argued that this was secondary to a tendency to hypocalcaemia caused by excessive urinary loss of calcium, which in turn resulted from a primary abnormality in the renal tubular handling of calcium. This argument is difficult to sustain since in idiopathic hypercalciuria the serum calcium concentration tends toward the upper limit of the normal range (Peacock et al., 1968). Furthermore the renal tubular reabsorption of calcium is generally normal in these patients (Peacock and Nordin, 1968). 